\author{
Jurnal Aplikasi dan Inovasi Ipteks "SOLIDITAS” \\ Vol. 1 / No. 1 / April 2018 ; 29-33 \\ ISSN 2620-5076
}

\title{
PENGARUH MODEL PISAU PADA MESIN SAMPAH BOTOL PLASTIK
}

\author{
Mochtar Asroni', Soeparno Djiwo², Eko Yohanes Setyawan ${ }^{3}$ \\ ${ }^{1,2,3}$ Jurusan Teknik Mesin, Fakultas Teknik Industri, Institut Teknologi Nasional Malang \\ 1'mochtar.asroni@yahoo.co.id
}

\begin{abstract}
ABSTRAK
Seiring peningkatan pemakaian botol plastik menyebabkan timbulnya sampah botol plastik semakin menumpuk. yang menuntut pengelolaannya dilakukan secara benar agar dapat mengatasi penumpukan sampah. Hal ini dapat diatasi dengan banyak cara, antara lain dengan menyusun botol plastik sedemikian rupa, sehingga kapasitas di dalam karung lebih banyak, merancang mesin pencacah yang nantinya akan digunakan untuk mencacah botol plastik sekaligus memperkecil jumlah transportasi yang digunakan pengepul plastik untuk disetorkan ke pabrik daur ulang. Hal ini juga dapat mengurangi dampak sampah botol plastik yang semakin hari semakin banyak terutama di lingkungan Kecamatan Lawang Kabupaten Malang. pencemaran lingkungan yang dapat menimbulkan masalah adalah pencemaran yang disebabkan oleh sampah plastik karena sulit didaur ulang. Pengelolaan sampah hendaknya menerapkan proses - proses, seperti Reduce (mengurangi), Reuse (menggunakan kembali), Recycle (mendaur ulang), Replace (mengganti barang berpotensi sampah ke arah bahan recycle) seperti yang dilakuan saat ini yaitu mencacah plastik yang nantinya bisa digunakan kembali. Konstruksi yang dirancang dan dibuat pada mesin pencacah botol plastik ini merupakan produk hasil modifikasi, yaitu produk yang sudah ada dengan mengalami perubahan - perubahan baik perubahan dalam bentuk dan ukurannya, bertujuan untuk meningkatkan efisiensi, efektifitas, kualitas, penampilan dan keamanan pada mesin sehingga mudah dalam penggunaannya. Selain itu mesin pencacah botol plastik yang akan dibuat ini bersifat portable sehingga nantinya bisa dikembangkan kembali untuk pencacah sampah plastik berjenis lainnya. Hasil analisa menunjukkan bahwa dengan menggunakan mesin teknologi tepat guna dapat meningkatkan nilai jual botol plastik bekas karena botol plastik bekas ini dijadikan biji plastik sehingga perusahaan yang menggunakan bahan baku plastik dapat langsung memakainya menjadi produk. Dalam proses menggunakan mesin dipengaruhi oleh model rancangan mata pisau dan rpm mesin. Untuk mendapatkan kualitas dan kuantitas produk yang maksimal pada model rancangan mata pisau bentuk $\mathrm{V}$ dan menggunakan rpm 800 dengan hasil yang didapat bentuk biji plastik yang kecil dan hasil yang didapat 1000 gram per menit.
\end{abstract}

Kata Kunci: Botol plastik, Produktivitas, Teknologi Tepat Guna.

\begin{abstract}
As the use of plastic bottles increases, plastic bottles build up. which requires proper management to be able to cope with garbage accumulation. This can be overcome in many ways, among others, by arranging plastic bottles in such a way that the capacity in the sack is more, designing a chopper machine that will be used to chop the plastic bottle while minimizing the amount of transportation that plastic collectors use to be deposited to the recycling plant. It also can reduce the impact of plastic bottle waste that increasingly more days, especially in the environment Lawang District Malang Regency. environmental pollution that can cause problems is pollution caused by plastic waste because it is difficult to be recycled. Waste management should implement processes, such as Reduce (Reduce), Reuse, Recycle, Replace (replacing potentially waste items to recycle materials) as currently practiced by recycling plastic that can be reused. The designed and manufactured construction of this plastic bottle machine is a modified product, that is, an existing product with changes in both shape and size changes, aiming to improve the efficiency, effectiveness, quality, appearance and safety of the machine so that it is easy to its use. In addition, plastic bottle counter machine that will be made is portable so that later can be developed again for other types of plastic waste takers. The result of analysis shows that by using the appropriate technology machine can increase the sale value of used plastic bottles because these plastic bottles used as plastic seeds so that companies using plastic raw materials can directly use them into products. In the process of using the machine is influenced by the blade design model and engine rpm. To get the maximum product quality and quantity on the model of blade design of $V$ shape and using rpm 800 with the result obtained form of small plastic seed and yield obtained 1000 gram per minute.
\end{abstract}

Keywords: Plastic Bottles, Productivity, Appropriate Technology. 


\section{PENDAHULUAN}

Penggunaan plastik dalam kehidupan manusia semakin meningkat. Peningkatan ini terjadi karena plastik bersifat ringan, praktis, ekonomis dan dapat menggantikan fungsi dari barang-barang lain. Sifat praktis dan ekonomis ini menyebabkan plastik sering dijadikan barang sekali pakai, sehingga semakin banyaknya penggunaan perlengkapan dari bahan plastik tersebut, menyebabkan sampah plastik menjadi menumpuk. Hal inilah yang menyebabkan jumlah sampah plastik meningkat terus menerus dan menyebabkan pencemaran lingkungan lingkungan.

Bahan plastik memang merupakan komponen penting dalam aktivitas kehidupan seharihari. Perannya sebagai pengganti logam dan kayu mendominasi pembuatan produk karena sifatnya yang sangat unggul antara lain: ringan, kuat, tahan korosi, transparan, dan sifat insulasi yang baik. Aplikasi pemakaian bahan plastik ini dapat ditemukan pada produk-produk kemasan makanan, alatalat rumah tangga hingga komponen produk otomotif. Konsumsi pemakaian bahan plastik tersebut dapat dipastikan mengalami peningkatan tiap tahun akibat bertambahnya tuntutan kebutuhan hidup. Seiring peningkatan pemakaian bahan plastik tersebut, menyebabkan timbulnya sampah plastik yang menuntut pengelolaannya yang dilakukan secara benar untuk dapat mengatasinya peningkatannya.

Salah satu bentuk pencemaran lingkungan yang dapat menimbulkan masalah adalah pencemaran yang disebabkan oleh sampah plastik yang sulit didaur ulang secara langsung. Pengelolaan sampah hendaknya menerapkan proses-proses, seperti Reduce (mengurangi), Reuse (menggunakan kembali), Recycle (mendaur ulang), Replace (mengganti barang berpotensi sampah ke arah bahan recycle). Dari berbagai macam sampah yang ada, salah satu jenis sampah yang masih bisa dimanfaatkan ulang adalah sampah plastik, yaitu dengan cara didaur ulang. Dengan dapat didaur ulang maka banyak potensi dari sampah plastik yang masih bisa dimanfaatkan. Untuk menunjang langkah tersebut maka dibuat suatu perancangan mesin untuk mengolah sampah untuk memperkecil volume dan meningkatkan daya jual yang nantinya disetorkan ke pabrik. Botol plastik dalam keadaan utuh tersebut, maka distributor harus menyediakan transportasi yang lebih besar dalam pengangkutan akibat volume yang besar dengan beban yang ringan. Hal ini dapat diatasi dengan banyak cara, antara lain dengan menyusun botol plastik sedemikian rupa, sehingga kapasitas di dalam karung lebih banyak. Akan tetapi hal ini tidak akan banyak menghasilkan perubahan. Cara lain adalah dengan mencacah botol plastik hingga menjadi potongan-potongan kecil, yang biasanya dilakukan dengan mengunakan gunting.

Dengan mengunakan mesin pencacah plastic, pengemasan sampah plastik lebih efisien dan mempunyai nilai jual yang tinggi. Untuk membantu memecahkan masalah para pengepul plastik di Kecamatan Lawang Kabupaten Malang, maka tim pengabdian masyarakat ITN Malang mencoba merancang mesin pencacah yang nantinya akan digunakan untuk mencacah botol plastik sekaligus memperkecil jumlah transportasi yang digunakan pengepul plastik untuk disetorkan ke pabrik daur ulang. Hal ini juga dapat mengurangi dampak sampah yang semakin hari semakin banyak terutama di lingkungan Kecamatan Lawang Kabupaten Malang.

\section{METODE}

\section{A. Proses Produksi Sabut Kelapa.}

Perancangan dilakukan per komponen dari keseluruhan unit kemudian dilakukan perakitan. Perancangan diakhiri dengan menghasilkan gambar desain berupa gambar kerja yang terdiri dari:

- Komponen unit masukan material

- Komponen unit pencacah botol plastik

- Komponen unit penyaluran hasil cacahan botol plastik

- Sistem transmisi daya

Pengujian dilakukan untuk mengetahui fungsi dan mekanisme kerja mesin pencacah sampah 
botol plastik. Bahan uji berupa sampah botol plastik yang berada di lingkungan. Jika unjuk kerja mesin belum optimal maka dilakukan modifikasi untuk penyempurnaan komponen maupun unit prototipe. Parameter yang digunakan untuk mengevaluasinya adalah kapasitas, ukuran cacahan, dan mekanisme kinerja mesin.

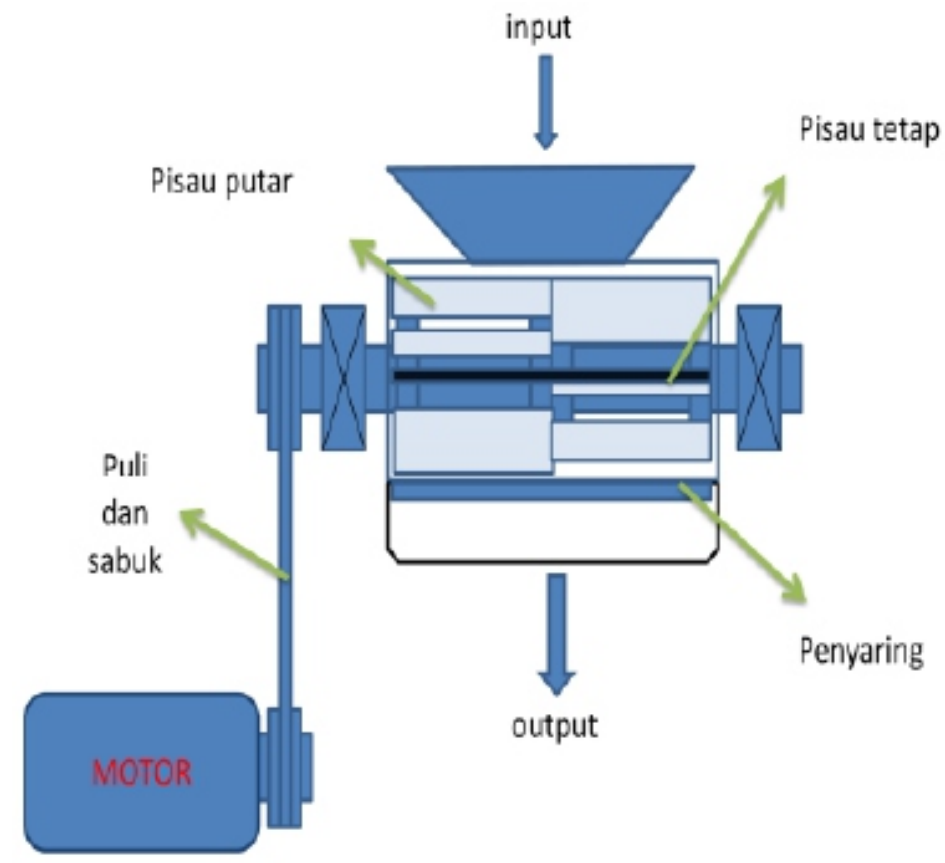

Gambar 1 Desain mesin pencacah botol plastik

A. Bagian - bagian dari Rancang Bangun Alat Pencacah Botol Plastik

1. Trasmisi

Transmisi adalah suatu alat untuk meneruskan tenaga dari poros satu ke poros yang lain dibantu dengan alat yang sesuai kebutuhan, misal alat itu rantai, sabuk, gear dll.

2. Poros

Poros adalah suatu bagian stasioner yang berputar, biasanya berpenampang bulat dimana terpasang elemen - elemen seperti roda gigi (gear), pulley, flywheel, engkol, sprocket dan elemen pemindah lainnya. Poros bisa menerima beban lenturan, beban tarikan, beban tekan, atau beban puntir yang bekerja snediri - sendiri atau berupa gabungan satu dengan yang lainnya.

3. Bantalan

Bantalan adalah elemen mesin yang menumpu poros berbeban, sehingga putaran atau gerakan bolak - baliknya dapat berlangsung secara halus, aman dan panjang umurnya. Bantalan harus cukup kokoh untuk memungkinkan poros secara elemen mesin lainnya bekerja dengan baik. Jika bantalan tidak berfungsi dengan baik maka prestasi seluruh sistem akan menurun atau tidak dapat bekerja secara semestinya. Jadi, bantalan dalam pemesinan dapat disamakan peranannya dengan pondasi pada gedung.

Dalam memilih bantalan yang digunakan, perlu diperhattikan hal - hal sebagai berikut :

1. Tinggi rendahnya putaran poros

2. Jenis bahan yang digunakan

3. Besar kecilnya beban yang dikenakan

4. Kemudahan perawatan.

Mesin ini menggunakan sumber tenaga penggerak berupa motor listik 1 fase dengan daya maksimum $1 \mathrm{Hp}$ dan tegangan yang digunakan adalah 220 volt serta mempunyai kecepatan putar poros sebesar $1425 \mathrm{rpm}$ dengan transmisi pulley belt. 


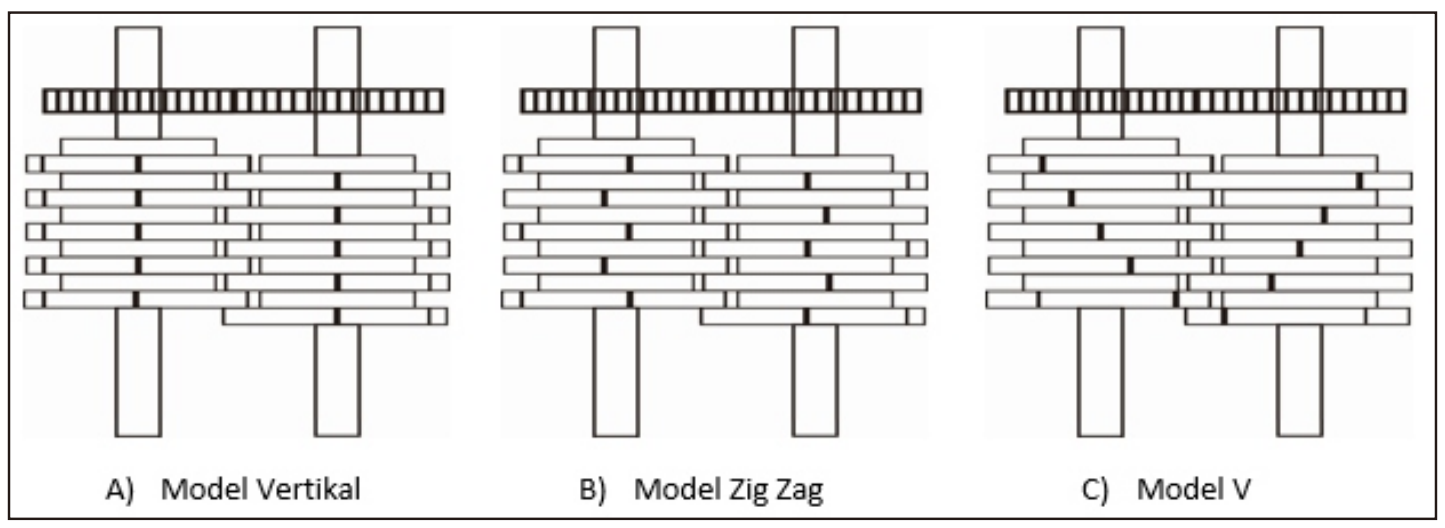

Gambar 2. Desain rancangan mata pisau

\section{HASIL DAN PEMBAHASAN}

Berdasarkan hasil pengamatan dan pengujian dapat dihitung hasil dari alat mesin pencacah botol plastik tersebut sebagai berikut dengan menggunakan persamaan rumus :

\begin{tabular}{|l|l|c|c|}
\hline No & Model mata pisau & Rpm & $\begin{array}{c}\text { Hasil serat } \\
\text { (gram / menit) }\end{array}$ \\
\hline 1 & Vertikal & 400 & 500 \\
\hline 2 & Zig zag & 600 & 800 \\
\hline 3 & V & 800 & 1000 \\
\hline
\end{tabular}

Tabel 1. Hasil uji alat pencacah botol plastik

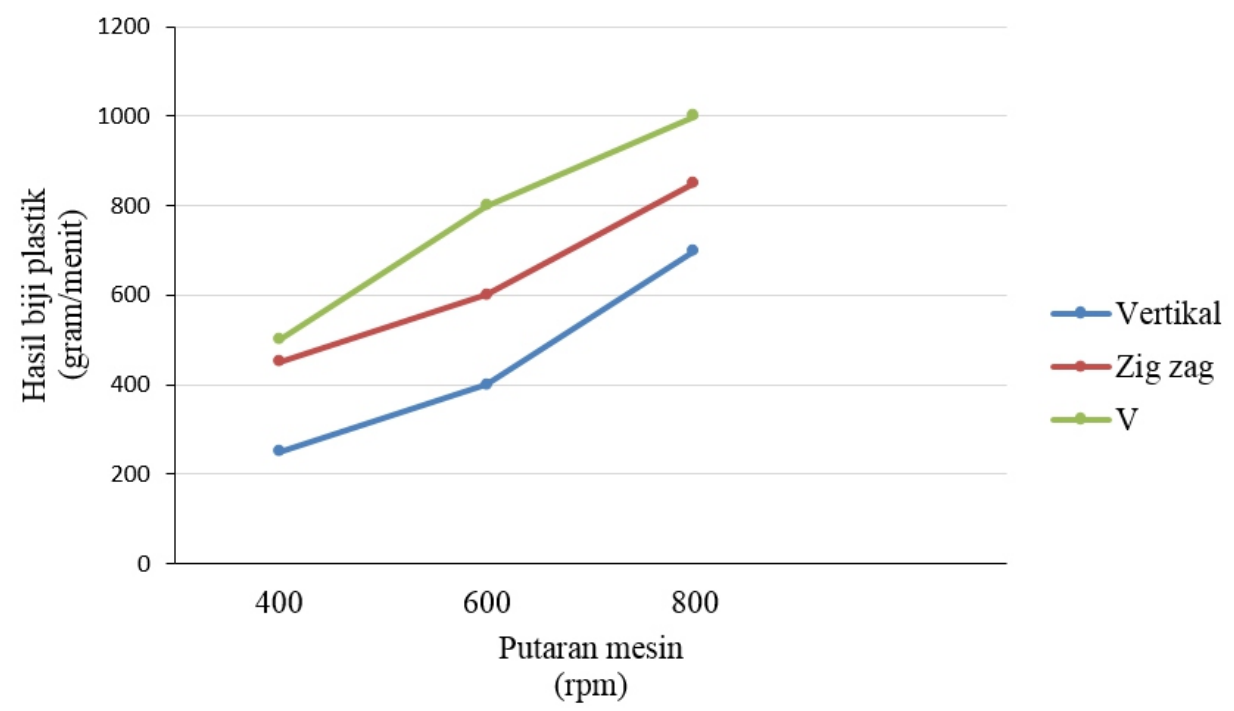

Gambar 3. Grafik hasil uji mesin pencacah botol plastik

Dari tabel dan grafik diatas, terjadi peningkatan kuantitas produk disetiap perubahan model rancangan mata pisau. Model rancangan mata pisau yang mempunyai nilai kuantitas tertinggi model mata pisau bentuk V. Hal ini dikarenakan pada saat proses pencacahan, rancangan mata pisau bentuk V mencacah plastik seperti model ulir sehingga botol plastik terjadi tarikan yang diakibatkan mata pisau dan mata pisau yang berlawanan memotong botol plastik tersebut sehingga pergerakan pencacahan botol plastik bergerak cepat.

Meninjau dari putaran mesin, kuantitas hasil biji plastik terbanyak pada putaran mesin 800 rpm. Pada penelitian yang pernah dilakukan, putaran mesin semakin tinggi maka pencacahan pada produk akan semakin cepat. Tetapi penggunaan pada putaran mesin terlalu tinggi tidak bisa 
dilakukan pada bahan - bahan yang mudah patah. Dalam pencacahan botol plastik ini dengan menggunakan rpm tinggi dapat dilakukan karena jumlah produk cacahan yang dihasilkan semakin banyak. Hal ini dikarenakan pada putaran mesin tinggi pergerakan mata pisau semakin cepat sehingga waktu pencacahan semakin cepat dan kuantitas hasil semakin banyak.

Selain meninjau dari kuantitas, dalam penelitian ini juga menganalisa dari kualitas hasil cacahan. Dari melihat hasil cacahan secara fisik, model rancangan mata pisau bentuk V mempunyai ukuran cacahan plastik kecil - kecil, sedangkan pada rancangan mata pisau model vertikal dan zigzag bentuk cacahannya memanjang. Dari perbedaan putaran mesin, semakin tinggi putaran mesin kualitas hasil cacahan mempunyai ukuran cacahan semakin kecil.

\section{DAMPAK DAN MANFAAT}

Dengan adanya mesin pencacah botol plastik ini, pada mitra telah mengalami peningkatan dari segi pendapatan yang dihasilkan. Selain itu juga dapat memperluas jaringan kerjasama dengan perusahaan - perusahaan plastik skala kecil untuk mensuplai bahan baku yang digunakan. Dengan meningkatnya jaringan - jaringan penerima hasil produk biji plastik, juga dapat memberdayakan pemulung atau pencari botol plastik bekas yang di daur ulang kembali menjadi biji plastik.

\section{KESIMPULAN}

Dari hasil penelitian didapatkan kesimpulan bahwa dengan menggunakan mesin pencacah botol plastik dengan perbedaan model rancangan mata pisau dan putaran mesin mempengaruhi kualitas dan kuantitas hasil cacahan. Pada model rancangan mata pisau dan putaran mesin $800 \mathrm{rpm}$ mempunyai kualitas hasil cacahan yang berukuran kecil dan kuantitas yang dihasilkan banyak dibandingkan model rancangan mata pisau lainnya. Kuantitas yang dihasilkan pada putaran 800 rpm dengan mata pisau bentuk V sebesar 1000 gram per menit.

\section{UCAPAN TERIMA KASIH}

Ucapan terima kasih disampaikan kepada Lembaga Penelitian dan Pengabdian ITN Malang yang telah mensupport dalam bentuk dana untuk kelancaran program penelitian dan pengabdian yang telah dilakukan.

\section{DAFTAR PUSTAKA}

Rott, Robert L. 1992. Machine Elemen in Mechanical Design. 2 nd ed. Maximillan Publishing Co. New York.

Rajaguguk, J. 2013. Analisis Perancangan Mesin Penghancur Plastik. Jurnal Dinamis Vol. II No. 12 Universitas Sumatera Utara.

Sularso. 1991. Dasar Perencanaan dan Pemilihan Elemen Mesin. 7th ed.

Gunadarma, U. 2008. Perancangan Mesin Pencacah Sampah Type Crusher. 20-21

Napitupulu, R., Subhkan, M., Nita, L. D. 2011. Rancang Bangun Mesin Pencacah Sampah Plastik. Jurnal Manutech 3(1) 1-5.

Prakoso, B. A. 2016. Perancangan dan Pembuatan Mesin Penghancur Botol Plastik Elektronik.

pingo, H., Djamalu, Y., dan Botutihe, S. 2016. Optimalisasi Mesin Pencacah Plastik Otomatis. Jurnal Teknologi Pertanian Gorontalo. Vol 1 No. 2 hal. 122- 139.

Iklas, N. 2009. Rancang Bangun Mesin Pencacah Plastik Untuk Meningkatkan Produktivitas Usaha Kecil Plastik Bekas.

Nur, I., Nofriadi, dan Rusmardi. 2014. Pengembangan Mesin Pencacah Sampah/Limbah Plastik Dengan Sistem Crusher dan Silinder Pemotong Tipe Reel. Seminar Nasional Sains dan Teknologi 2014 Universitas Muhamadiyah 